\title{
Trading Phases
}

NEW RULES FOR OTC DERIVATIVES WILL MAKE COLLATERAL MANAGEMENT KEY

\section{By Sherree DeCovny}

When global regulators mandated that standardized overthe-counter (OTC) derivatives must be centrally cleared and counterparties must put up margin against their positions, various sources predicted huge overall collateral costs to the industry. Participants are not only learning to manage the problem through collateral transformation and optimization, but some are also turning collateral management into a profit center.

Counterparties used to bilaterally settle OTC derivatives and collateralize their positions. When a bank transacted a swap, for example, it would extend a credit line to its customer. As long as the value at risk (VaR) of the customer's trades stayed below that credit line, no collateral

Variation margin on over-the-counter (OTC) derivatives trades is being phased in starting in September 2016.

Optimization and transformation could save costs and potentially generate profits.

Workflows and the competitive landscape are set to change. was posted. Once the VaR went above the credit line, the bank would require collateral. One way of doing this was by placing a lien against the customer's assets at the bank. The swaps portfolio and the collateral would be valued periodically, usually daily, and the amount of collateral needed was adjusted accordingly.

In lieu of a lien on existing assets, the bank would accept cash or certain securities as collateral. Because the collateral did not actually move, the customer would still be entitled to interest, dividends, and capital appreciation.

But that is changing. In the US, sell-side participants will be required to post variation margin-daily payments made to alleviate exposure because of high-risk positions-beginning 1 September 2016, and the deadline for buy-side firms is 1 March 2017. There will be phased-in compliance for initial margin requirements from September 2016 to September 2020. Europe plans to implement its margin rules along the same timeline.

Trade counterparties will have to post collateral with a clearing member such as a futures commission merchant, who, in turn, will post collateral with the clearinghouse. Eligible collateral typically includes cash, government instruments, or other high-grade securities, usually with a short maturity (i.e., under five years). Collateral must be posted with the clearinghouse by market open on $T+1$. The collateral will be physically moved and held in the clearinghouse's custodial account.
Positions will be marked to market daily. The counterparty whose position has depreciated must send variation margin in cash to the clearinghouse, which, in turn, will give that money to the counterparty whose position has appreciated in value. Ultimately, this protects the clearinghouse.

Firms are increasingly optimizing their collateral, which involves running multiple scenarios to identify which assets to pledge. The determination must take into account trading strategies, cost of funding, availability, haircuts (the difference between the market value of a collateral asset and the loan amount), potential future exposure, and reinvestment rates. Other factors to consider are the number of pieces of collateral being moved, the number of substitutions required, and where the assets are being held.

"There may be no point pledging 10 different pieces just because they may be cheaper on the face value than one or two larger pieces," says Helen Nicol, director, COLLINE collateral, clearing and optimization at Lombard Risk. "By the time you've taken in the operational costs and the cost of substitution, then the actual overall effect may not be cheapest to deliver."

Firms are also transforming collateral so they can post a wider range of collateral than a clearinghouse can accept. For example, a clearing member firm may be able to accept corporate bonds as collateral from a customer, post government notes on the customer's behalf with the clearinghouse, and then charge the customer a fee for the service.

\section{WORKFLOW CHANGE}

Some participants will have to climb a steeper learning curve than others once the new rules take effect, notes James Malgieri, executive vice president and CEO of broker/dealer services at BNY Mellon's Markets Group.

The equity financing desks of large sell-side firms have been optimizing and transforming collateral for decades. For example, borrowing US treasuries or other G-7 debt and pledging other types of collateral is a straightforward upgrade trade. Moreover, buy-side firms that trade listed derivatives are used to posting collateral through their clearing broker (investment institutions such as ' 40 Act funds take leverage), so they request that custodians lock up collateral in segregated accounts, sometimes under an account control agreement.

Sell-side firms are taking clearing and collateral charges into account when pricing trades, adds Virginie O'Shea, senior analyst at Aite Group. Credit value adjustment desks are tasked with determining the market value of counterparty credit risk. They analyze the cost of pledging collateral and monitor the eligibility requirements and haircuts at various clearinghouses. 
Soon, all counterparties for OTC derivatives will need to calculate and confirm their variation margin daily. Either they will do it themselves or outsource it. The margin process itself will not change dramatically; it will involve issuance, eligibility checks and controls, response from the counterparty, pledging of the collateral, booking of the collateral, and settlement. But, depending on the relationship between the counterparties, collateral may have to be moved to secure the variation margin.

Firms used to have just one agreement with their bilateral counterparty, but now they will need separate agreements drawn up for cleared and uncleared transactions. Alternative investment managers often execute swap transactions with a few counterparties on behalf of multiple funds. As a result, these firms have many credit support annexes (CSAs) - which regulate collateral for derivatives transactions-all with different collateral schedules.

"Large firms engaged in that type of activity are looking across their CSAs and trying to harmonize their collateral schedules," says Malgieri. "They're also putting tools in place to provide visibility of collateral eligibility across their CSAs."

Not surprisingly, there is a move toward implementing an intelligent and agile workflow with more streamlining, automation, control, and exception-based processing.

"Organizations don't want to dramatically increase their headcount, but they need some form of dealing with the increase in volumes," says Nicol. "They're looking for something that's going to handle the volumes, scale appropriately, and take away some of that manual intervention wherever possible."

Pre-trade, the front office will need to perform "what if?" scenario analysis to figure out whether a transaction will be cleared or uncleared. If it needs to be cleared, they need to choose a clearinghouse. If they have a portfolio of trades at a certain clearinghouse, they need to decide whether it is better to clear the new trades there or elsewhere or to move the entire portfolio to another clearinghouse. They need to determine whether trades can be netted. Finally, they need to consider whether it is a house or client trade; if it is the latter, they will need to determine whether the client prefers one clearinghouse over another.

Going forward, collateral will increasingly be posted in the form of securities instead of cash, and that will have an impact on trading decisions. For example, because insurance companies' portfolios tend to be fully invested, if they need to raise cash, they can do a transformation trade in which they lend the securities in their portfolio and receive cash. If portfolio managers do not have the securities that the counterparty or the clearing broker wants, they need to find the right collateral to do a transformation trade.

\section{A CHANGING COMPETITIVE LANDSCAPE}

Buy-side firms such as funds will likely need transformation services. The clearing broker will tell the fund how much collateral is needed. The custodian, under the instruction of the fund, will lock the collateral up on his or her books and produce a report for the clearing broker to show that the collateral is locked up to their benefit. Then the clearing broker will post cash at the clearinghouse.

Whether buy-side firms will use optimization depends on how they manage their portfolios and their fund structure. According to Malgieri, funds generally will not be able to get the same benefits a broker/dealer would by centralizing and optimizing all of their collateral.

"When they want to segregate collateral on our books, we open up hundreds of accounts," he says. "They can't commingle the collateral they receive, and therefore they can't commingle the collateral when they need to post it."

Smaller buy-side firms that trade derivatives infrequently may find it too expensive to have their custodians open segregated accounts for managing collateral. Instead, they may simply stop trading OTC derivatives and, depending on the type of fund, find other ways to hedge their books.

"If they decide to stay in this space, it's going to be a drag on portfolio returns," Malgieri adds. "It's going to manifest itself through the increased costs of doing this type of activity and the operational expense needed to perform the functions."

Clearing brokers have the capacity to service only a limited number of clients, and they are retaining the larger ones so they can earn higher commissions. In Europe, some clearing brokers have left the business for various reasons, such as the high cost of doing business and regulatory uncertainty. However, sell-side firms that want to remain competitive may have to be more open to negotiating what collateral they will accept.

"There are some discussions about different models for going direct to market, but that's quite challenging," says O'Shea. "Circumventing a clearing broker means that you have to hold capital and have connectivity to the clearinghouses yourself, which is not easy for buy-side firms."

For now, participants should be getting ready for the next round of changes. Sell-side firms will need to be savvy about centralizing collateral across their legal entities as well as managing data and leveraging it to make better trading decisions. Meanwhile, buy-side firms should be working to understand their expenses and the impact of the regulations on their portfolios. They should also be hiring staff who can test and implement new processes and technology in preparation for the deadlines.

"Swap Meet: Before Swap Futures Take Off, sers Must Climb a Steep Learning Curve," CFA Institute Magazine (September/October 2015) [www.cfapubs.org]

"Of Tigers and Tails: In a World of Low Yields and Reactive Monetary Policy, the Difference between Chasing Return and Portfolio Construction Has Become Vital," CFA Institute Magazine (November/ December 2015) [www.cfapubs.org]
Sherree DeCovny is a freelance journalist specializing in finance and technology. 